\title{
Improving Students' Learning Outcomes in Advanced Fashion Design Course by Using Portfolio Instrument
}

\author{
Sicilia Sawitri ${ }^{1}$, Wulansari Prasetyaningtyas ${ }^{2}$, Rodya Syamwil ${ }^{3}$, Taofan Ali Achmadi ${ }^{4}$, \\ Partini $^{5}$, Nur Qurroti Ainina ${ }^{6}$ \\ \{ sicilia.sawitri@mail.unnes.ac.id ${ }^{1}$,wulan_sari@mail.unnes.ac.id ${ }^{2}$, rodiasyamwil@yahoo.com³ \\ taofanali@gmail.com ${ }^{4}$,partinitini084@gmail.com ${ }^{5}$, qurotiainina@gmail.com ${ }^{6}$ \} \\ Universitas Negeri Semarang 1,2,3,4,5,6
}

\begin{abstract}
In the instructional process, there are so many activities, before the lesson begins, during the lesson and after. After the lesson the lecturers always do the assessment. The developing portfolio as an assessment was one of many assessments techniques in Advanced Fashion Design Course. The aim of the study was to find the improving students learning outcome in Advanced Fashion Design Course by applying portfolio as an assessment instruments. The research method was experiment design. By using pretestposttest design the research was conducted. The data was analyzed by using descriptive percentage and gain score. The students' outcome before the experiment was $70.26 \%$ and after $80 \%$. By using gain score to analyze the improving the students ${ }^{6}$ outcomes were 0.33 it was medium category. This was because students were not familiar with portfolio as an assessment and lack of discipline in submitting the assignments.
\end{abstract}

Keywords: Improving, the students‘ learning outcomes, Advanced Fashion Design, portfolio.

\section{Introductions}

The Fashion Education study program in addition to preparing graduates to become teacher $\mathrm{s}$ at vocational high schools, also prepare graduates to work as fashion designer who can work independently as fashion designer or work in fashion industry, and entrepreneur. The Fashion Education is one of Study program in Department of Family Welfare Education, There are 4 study programs in Department of Family Welfare Education, Fashion Education, Culinair Education, Cosmetic Education and Family Welfare Education. The Fashion Education study program began in 2014, previously a expertise program in The Family Welfare Education Department. After the students finished their study, they have some qualification such as professional skill in fashion, teaching, concerned about environmental, social and culture [1]

There are many courses in Fashion Education Study Program, including Pattern Making (manual and computerized), Basic of Fashion Design, Fashion Design, Fashion Trend, Clothing Technology, Draping, Fashion Complement, Fashion enterprise and Ultimate Service, Advance Fashion Design, and other. One subject which prepares the students to be a fashion designer is Advanced Fashion Design. All of the subjects need a good instructional process. In the instructional process, there many activities, before the lesson, include lesson plan, preparing evaluation instrument, instructional media, during the lesson, the lecturers always do the assessment. The assessment of students' learning outcome is basically an integral part of the 
instructional process, which needs to be directed to assess student performance [2]. There so many instruments can be used in assessment the students outcomes, one of the way in assessments are applying portfolio as assessment instrument. The portfolio can be used at various level of education [3], it can be used as self-assessment [4].

The impact of portfolio in the research by Scartabello, Abate, Slimak, can develop students' self-assessment skill, it can be improvements and can be extrapolated to students on many academic disciplines [4]. The assessment portfolio model is suitable for subject that requires students learning out puts in terms of knowledge, skill and attitude [5].

This assessment is in the form of an assessment of a group of students' works that are systematically arranged and organized which are taken during the learning process within a certain period of time. Therefore teachers should use this assessment so that the quality of learning can be improved.

In Advance Fashion Design course, the students are required to create various design for various occasions, based on analysis of fashion from time to time. These assignment are collected and assessed using a portfolio as instrument.

The aim of the study, was to know the improving students' learning outcomes in the Advanced Fashion Design course by using portfolio as assessment instrument.

\section{The Portfolio in Advanced Fashion Design}

The Advanced Fashion Design course is one of the subjects in Fashion Education study program.. Some of the subjects are offer to the students. One of the subjects is Advanced Fashion Design. The Advanced Fashion Design consist of several topics, including: fashion proportion, design development from part of clothing, fashion analysis, creating new design based on fashion analysis, fashion design portfolio, collection creating, and designing based on films local or international.

The abilities that be mastered by students after attending the Advanced Fashion Design course were: Fashion illustration concept, drawing body proportion without measuring instruments, skilled at developing designs by imitating and arranging (stylists), analyzing the form of fashion from the past until now by research, compiling collection, creating fashion designer portfolio and drawing fashion for promotion manually or digitally for various fashion businesses.

In Advanced Fashion Design instructional process starts with planning, actuating and evaluating. In evaluating process always needs instrument for assessment. There are several evaluation instruments. Portfolio instrument is one of instrument in assessing students work individual or classical in period for a teaching material.

In general, a portfolio is a collection of document of a person, group, institution, company, organization which documenting the progress of a process in achieving predetermined goals [5], Now a days the portfolio is recommended type of assessment which can be used by teacher at school [6]. The portfolio provides several benefits for teacher [7] including the teacher will concentrate of development rather than on the final results. The portfolio can be used by students to collect all documents relating to the science that are learned both in the classroom and outside the classroom, including outside of school [8]. At the end of period of work is collected and assessed the lecturers and the students themselves.

The advantages of portfolio lie in its ability to increase student activity, because motivation can increase. The condition makes students feel more value, so that their motivation to learn 
increases. The portfolio can describe the continuity of student progress rather than snapshot of students' outcome in single occasion test [6]. The disadvantages lie in the difficulties of matching students' environmental condition when taking grades, even though the assessment takes place over a long period of time. The weakness also lies in the higher cost, time requirements which are more complicated because of comparing the work of one student from time to time, the lecturer also compares the result between the students.

The application of the portfolio in Advanced Fashion Design course, was giving assignments to the students, including the objectives, materials, assignment to create some new fashion designs, then conducting an assessment. The assessment was carried out by the lecturer with assessment criteria in fashion design, including body proportion, inspiration, fashion drawing technique, creativity, coloring, type of fashion, cleanliness, discipline.

\section{Research method}

Fashion Education Study Program students were the samples in this research, consisting of $4^{\text {th }}$ semester students, totaled 27 people. By using pretest-posttest experiment design the research was conducted.

The first analysis used percentage descriptive [9] and the second analysis used gain score. The gain score analysis is used to determine the increase of students' learning outcome in the Advanced Fashion Design course [10]

The first data analysis

$$
\mathrm{P}=\frac{\mathrm{f} \times 100 \%}{\mathrm{~N}}
$$

$$
\begin{array}{ll}
\text { Where: } & \mathrm{f}=\text { Subject frequency } \\
\mathrm{N}=\text { Total number [9] }
\end{array}
$$

The second data analysis

Gain score analysis was used in this research, to determine the increasing of students' outcome in the Advanced Fashion Design course.

$$
(\mathrm{g})=[\%(\mathrm{Sf})-\%(\mathrm{Si})] /[100-\% \mathrm{Si})]
$$

Figure 2. Average Gain Formula

Where:

$$
\begin{aligned}
& \mathrm{g}: \text { : Gain score } \\
& \text { Sf : final test (post) } \\
& \text { Si : initial (pre) test }
\end{aligned}
$$


Table 1. Gain Criteria [10]

\begin{tabular}{ccc}
\hline No & Average Gain & Criteria \\
\hline 1 & $\geq 0.7$ & High-g \\
2 & $0.7>-\geq 0.3$ & Medium-g \\
3 & $<0.3$ & Low-g \\
\hline
\end{tabular}

\section{Research result and discussion}

\subsection{Research result}

The results of the research, by using descriptive analysis, showed the students outcome in Advanced Fashion Design course, before and after being given learning by applying a portfolio as an assessment instrument, were $70.26 \%$ for the pretest and $80 \%$ for the posttest, as shown on table 2 .

Table 2. Students' outcomes

\begin{tabular}{crcc}
\hline No & Pre-test and Post-Test & Persentasi & Kriteria \\
\hline 1 & Pre - Test & $70.26 \%$ & Baik \\
2 & Post - Test & $80 \%$ & Baik sekali \\
\hline
\end{tabular}

(Research data)

The result on the table above, then to determine the increasing students' outcome in Advanced Fashion Design, used gain-score analysis, obtained 0.33 including the medium category (medium -g criteria)

\subsection{Discussion}

The result showed the pre-test was $70.26 \% \$$ in the good category. This was because the Advanced Fashion Design course was the third subject in Fashion Design in Fashion Education study program. The first was Basic Fashion Design, Fashion Design. The third was Advanced Fashion Design. However, there are still deficiencies, when viewed from body proportion, application of design element and principles, selection of source based on fashion analysis, understanding of fashion style, presentation techniques still need a lot of practice.

During the learning process, in 3 credits of semester, the duration of the lecture was $6 \times 50$ minutes, it was hope that students could develop the creative design. The students outcomes in post-test was $80 \%$, in good category. The higher score was 86 and the lowest score was 72 . The improving of students' outcome was 0.33 based on the gain-score analysis, it was medium category. This showed the increase from pre-test to post-test score was not so high. It can be higher in the future time by improving learning facilities and infrastructure, providing motivation for students, that to become fashion designers must be proficient in developing ideas based on everything in this world.

The study conducted by Nurhayai and Yulistiana, contributed to learning, titled ribbon embroidery competent in the subject of decorating clothes at SMK Budi Utomo Perak Jombang, was successful, by applying the portfolio as assessment, the study was successful. The average 
value was 75. The higher score was 91 and the lowest was 70. This showed that portfolio can be used as an alternative evaluation tool in the subject of Fashion Decoration. It can even be applied to other subjects 11]. The portfolio assessment can increase students' English motivation, this finding can help the lecturer improve their pedagogical skill, help the students, while helping to increase their students' learning outcomes [12]. The use of a portfolio-based learning model can improve students learning outcomes and learning activity [13]

The portfolio instrument can improving students' learning outcomes in Advanced Fashion Design course, based on the analysis data and some researcher results. Assessment portfolio apart from being carried out by lecturers, parents, and students. In this research the parents did not do the assessment, because the parents live outside the city of Semarang, only the lecturer did the assessment.

\section{Conclusion}

There was improvement in students' learning outcomes in the Advanced Fashion Design course by using the portfolio as an assessment tool

The overall improvement students' learning outcomes was 0.30 incl uding in the medium category.

\section{References}

[1] Program Studi Tata Busana. : Kurikulum Pendidikan tata Busana tahun 2015. Semarang: Program Studi Pendidikan Tata Busana, FT, UNNES (2015)

[2] Abas, T, Jubaedah, Y, Widiaty. : Rancang bangun model portofolio based assessment pada kompetensi kejuruan siswa SMK, Jurnal IVOTEC, Volume IX, no. 1, Februari 2019.

[3] Yurdabakan, I, Erdogan, T.: The effect of portfolio assessment on reading, listening and writing skill of secondary school prep class students, The Journal of International Social Research Volume2/9, Fall 2009

[4] Scartabello, T, Abate, M.: Impact of Portfolio Program on Self-assessment skills involving Geeral longitudinal Outcomes.International Journal of ePortfolio, volume 8, number 1, (2018)

[5] Setiamihardja, R.: Penilaian Portofolio dalam Lingkup Pembelajaran Berbasis Kompetensi, https://media.neliti.com/media publication 240753,

[6] Afrianto, : Challenges of using portfolio as an alternative assessment method for teaching English in Indonesian School, International Journal of Educational Best Practices (IJEBP), vol 1, No. 2 (2017.)

[7] Murphy, S, Smith MA.: Writing portfolios a bridge from teaching to assessment, Ontario: Pippin Publishing Corporation (1992)

[8] Sumarna S. dan M. Hatta.: Penilaian Berbasis Kelas Penilaian Portofolio Implementasi Kurikulum 2004;, Bandung: PT Remaja Rosdakarya (2004,)

[9] Ali, M.: Strategi Penelitian Pendidikan. Bandung: Angkasa(1993).

[10] Hake, R.R.: Interactive-engagement versus traditional methods: A six-thousand student survey of mechanics test data for introductory phisics course. American Journal of Physics 66, 64 doi: 10.1119/1.18809. View online: http://dx.doi.org/10.1119, (1998);

[11] Nurhayati, Yulistiana.: Penerapan portofolio pada mata pelajaran menghias busana kompetensi sulam pita kelas XI busana butik di SMK Budi Utomo, Perak, Jombang. E journal UNESA, Edisi Yudisium Periode Agustus (2015).

[12] Hung, LC.: Alternative assessment: Can portfolio assessment have positive impact on EFLab original students' learning outcomes, International Journal of Management and Applied Science, Volume 2, issue 9 (2016).

[13] Rambe, A, Anggraini, Y.: Penerapan Model Pembelajaran Berbasis Portofolio untuk Meningkatkan hasil Belajar Menggambar Busana di SMK Negeri 8 Medan, Jurnal Tabularasa PPS UNIMED vol 11. No. 1, (2014) 
Students' assignment in Advanced Fashion Design

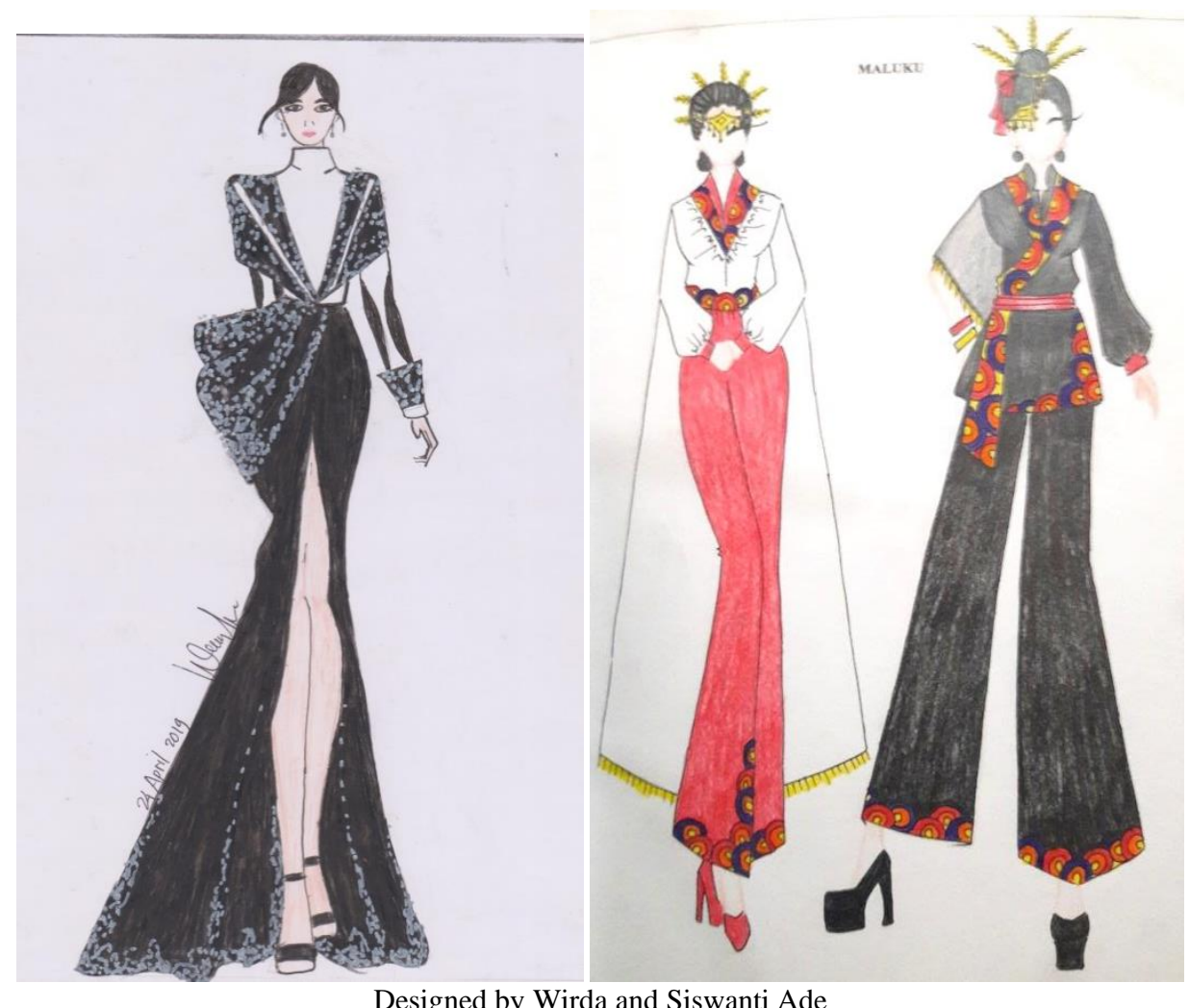

Designed by Wirda and Siswanti Ade 